\title{
To compare the efficacy of alternate day versus everyday dosing of atorvastatin in hyperlipidemic rabbits
}

\author{
Sarita Mulkalwar*, Pravin Golande
}

Department of Pharmacology, Dr. D. Y. Patil Medical College, Pimpri, Pune, Maharashtra, India

Received: 14 January 2016 Accepted: 09 February 2016

*Correspondence to:

Dr. Sarita Mulkalwar,

Email: smulkal@hotmail.com

Copyright: (c) the author(s), publisher and licensee Medip Academy. This is an openaccess article distributed under the terms of the Creative Commons Attribution NonCommercial License, which permits unrestricted noncommercial use, distribution, and reproduction in any medium, provided the original work is properly cited.

\begin{abstract}
Background: Muscle pain is often seen with statin therapy. Statins have also been associated with increase in liver transaminases as they lead to hepatic injury. The half - life of atorvastatin is increased due to its active metabolites which suggest the possibility for its alternate day use over everyday use. This would mean reduction in side effects such as hepatotoxicity and myopathy and solving the problem of statin underutilization in patients of lower socio economic class.
\end{abstract}

Methods: Institutional Animal Ethics Committee (IAEC) approval was taken before the start of study. Hyperlipidemia was induced in New Zealand White rabbits by oral administration of high fat diet for 3 weeks. After 3 weeks all the laboratory tests were done to see if animals had developed hyperlipidemia. This day was considered as day 0 for further study. Hyperlipidemic rabbits were divided into two groups, first group receiving atorvastatin orally $(5 \mathrm{mg} / \mathrm{kg})$ daily for duration of 6 weeks while the other group receiving atorvastatin orally $(5 \mathrm{mg} / \mathrm{kg})$ at alternate days for same duration. All the laboratory tests were done at week 3 and week 6 . Both the treatment groups were compared pairwise and also with day 0 to check for efficacy and safety.

Results: At the end of 6 weeks every day and alternate day dosing of atorvastatin, showed a statistical decrease in total cholesterol, triglycerides and LDL-C with respect to day 0 . Pairwise comparison did not show any statistical difference in between the two treatment groups. Statistical increase in HDL-C was seen only with everyday dosing of atorvastatin as compared to day 0 . Pairwise comparison showed statistical difference in between two treatment groups.

At the end of 6 weeks, there was no statistical difference in SGOT, SGPT and CK levels when compared to day 0 .

Conclusions: Alternate day dosing of atorvastatin was as efficacious and safe as everyday dosing of atorvastatin in hyperlipidemic New Zealand White rabbits, thus being a cost effective alternative.

Keywords: Atorvastatin, Hyperlipidemia, Rabbits

\section{INTRODUCTION}

Hyperlipidemia or a high level of serum triacylglycerol and cholesterol is a risk factor for premature atherosclerosis. Cardiovascular disease (CVD) is the most common contributor of morbidity and mortality worldwide. In fact it is a less recognized fact that the developing countries contribute a greater share to the global CVD burden than the industrialized countries. Pharmacological treatment of hyperlipidemia in conjunction with therapeutic lifestyle changes can be used for both primary and secondary prevention of CVD.
Statins are currently the cornerstone of therapy in patients with CVD. Among all the pharmacological and non pharmacological measures of LDL-C lowering, statins are the most effective and result in greatest clinical benefit. Placebo controlled trials using statins in standard doses have demonstrated a reduction in cardiovascular mortality by $20 \%$ and major cardiovascular events by $25 \%{ }^{1}$

Muscle pain is often seen with statin-based myopathy. Some studies have suggested that a quarter or even upwards of a third of patients who take statins will sooner or later develop a clinically significant myopathy. ${ }^{2}$ 
Statins have also been associated with increase in liver transaminases as they lead to hepatic injury. 30 cases of liver failure associated with statin use were reported to the FDA between 1987 and $2000 .^{3}$

Atorvastatin is a structurally distinct synthetic compound. It reduces the conversion of HMG-CoA to mevalonate, thus inhibiting an early and rate-limiting step in cholesterol biosynthesis. It has a half - life of 14 hours. Currently it is used every day in different doses as per the reduction in LDL-C is desired. Metabolism of atorvastatin proceeds chiefly through CYP3A4. Active metabolites are formed which also have some HMG-CoA reductase inhibitory activity. ${ }^{3}$ This increases the duration of action of the drug even further. Under steady state conditions, small amount of the parent drug and its metabolites produced in the liver can be found in the systemic circulation.

The apparent additive effect of active metabolites to the parent drug suggests us the possibility for its alternate day use over everyday use. Patients of the lower socioeconomic status may discontinue statin therapy due to prohibitive costs. Alternate day dosing may therefore solve the problem of statin underutilization. In clinical practice this would mean reduction in side effects such as hepatotoxicity and myopathy.

Some of the studies have shown that the alternate day dosing of atorvastatin is not as effective as daily day dosing, while other studies have indicated equal effectiveness in both the treatment groups. Due to such discrepancy, this study was planned to compare the efficacy of alternate day atorvastatin with everyday dosing in hyperlipidemic rabbits.

\section{Aim and objectives}

\section{Aim}

- To compare the efficacy of alternate day versus everyday dosing of atorvastatin in hyperlipidemic rabbits.

\section{Objectives}

- To compare the efficacy of alternate day versus everyday dosing of atorvastatin in hyperlipidemic rabbits.

- To compare the safety of alternate day versus everyday dosing of atorvastatin in hyperlipidemic rabbits.

\section{METHODS}

\section{Animals and their maintenance}

\section{Animals used}

The animals used in the present study were procured from the animal house of Dr. D.Y. Patil Medical College,
Pimpri, Pune. They were experimentally naïve and selected as per the following criteria:

Species: Oryctolagus cuniculus

Strain: New Zealand White Rabbits

Sex: Male

Weight: $1.5-2.5 \mathrm{~kg}$

Total number of animals used $(n)=12$

\section{Animal feed}

Animals were fed chow consisting of green leafy vegetables, lettuce, carrots, cucumber and tomatoes. Drinking tap water supplied by Pimpri Chinchwad Municipal Corporation was provided to the rabbits. Food and water was replenished daily.

\section{Animal housing}

Rabbits were housed individually in standard stainless steel cages at $24^{0} \mathrm{C}$ and relative humidity $(55 \pm 10 \%)$ and 12 h light: dark cycle. Apart from daily replenishment of food and water, the rabbits were left undisturbed.

The study was carried out in accordance with the guidelines given by Committee for the Purpose of Control \& Supervision of Experiments on Animals (CPCSEA), New Delhi (India). The study was approved by Institutional Animal Ethic Committee (IAEC) of Dr. D. Y. Patil Medical College, Pimpri, Pune.

\section{Drugs/chemicals used}

1. Study Drug: Atorvastatin calcium Dose: $5 \mathrm{mg} / \mathrm{kg}$ body weight Source: Emcure Pharmaceuticals (Pune)

2. High fat diet: Cholesterol powder + coconut oil. Cholesterol powder source: Research Lab, Fine Chem. Industries, Mumbai Coconut Oil source: Marico industries (Mumbai)

\section{Methodology}

Normal diet was given for 1 week for acclimatization of the rabbits. After acclimatization, lipid profile, serum transaminases (SGOT, SGPT) and creatine kinase (CK) measurements were done after overnight fasting. These values were considered as baseline

Hyperlipidemia was induced by oral administration of high fat diet - HFD (Cholesterol powder $500 \mathrm{mg} / \mathrm{kg}$ body weight mixed with $5 \mathrm{ml}$ coconut oil) for 3 weeks. After 3 weeks all the laboratory tests were done to see if animals had developed hyperlipidemia. This day was considered as day 0 for further study. 
Hyperlipidemic rabbits were divided into two groups, first group receiving normal diet + HFD + atorvastatin orally $(5 \mathrm{mg} / \mathrm{kg})$ daily for duration of 6 weeks while the other group receiving normal diet + HFD + atorvastatin $(5 \mathrm{mg} / \mathrm{kg})$ orally at alternate days for same duration. All the laboratory tests were done at week 3 and week 6 .

\section{Method of administration of atorvastatin ${ }^{4}$}

- Atorvastatin suspended in water containing $0.5 \%$ carboxymethylcellulose (CMC) was administered orally to all the 2 groups via feeding tube in addition to the regular normal diet for 6 weeks

\section{Method of inducing hyperlipidemia ${ }^{5}$}

- A high fat diet (HFD) was prepared by mixing cholesterol powder $500 \mathrm{mg} / \mathrm{kg}$ BW with $5 \mathrm{ml}$ coconut oil

- HFD was administered PO (per oral) with a feeding tube. HFD was given in addition to normal diet for a total duration of 9 weeks

\section{Groups}

Group 1: Normal diet + HFD + atorvastatin $5 \mathrm{mg} / \mathrm{kg}$ every day for 6 weeks $(n=6)$.

Group 2: Normal diet + HFD + atorvastatin $5 \mathrm{mg} / \mathrm{kg}$ on alternate days for 6 weeks $(n=6)$.

\section{Marginal ear vein blood withdrawal}

Rabbit was placed in a rabbit restrainer. Using clippers, the hair from the ear was removed. The ear lobe was gently stroked and tapped so as to make the ear veins visible. After locating the marginal ear vein, the site was disinfected using spirit gauze. The operator's non dominant hand was used to pull the ear taut. Using the dominant hand, a 22 gauge, 1 inch needle with an attached syringe was inserted and $5 \mathrm{ml}$ blood sample was withdrawn. Care was taken not to take any more blood than was needed. After blood withdrawal, a clean sterile, gauze pad was gently pressed over the site for a few seconds until the bleeding had stopped. The animal was returned to its cage for recovery.

\section{Laboratory analysis}

Lipid profile, SGOT, SGPT and creatine kinase (CK) levels were estimated in Central Clinical Laboratory of Dr. D.Y Patil Medical College, Pune.

\section{Statistical analysis}

The statistical analysis of the study was done using statistical package SAS (Version 9.2 for Windows).
Results are expressed as mean \pm S.D and statistical significance between means was analyzed using one-way analysis of variance (ANOVA) followed by Tukey multiple comparison test. Value of $\mathrm{p}<0.05$ was considered as statistically significant.

\section{RESULTS}

Table 1 and Figure 1 depict the change in lipid profile, SGPT, SGOT and creatine kinase (CK) when comparison was done between the baseline and day 0 . There was a statistical difference in all the parameters at day 0 when compared to the baseline.

Table 1: Represents the values taken at baseline and at day $0 . P$ - values are represented in the table.

\begin{tabular}{|lll|l|}
\hline Parameter & $\begin{array}{l}\text { Baseline } \\
(\text { Mean } \pm \text { SD })\end{array}$ & $\begin{array}{l}\text { Day 0 } \\
(\text { Mean } \pm \text { SD })\end{array}$ & P-value \\
\hline TC & $65.33 \pm 12.49$ & $84.17 \pm 16.46$ & $<0.0001$ \\
\hline TG & $67.25 \pm 12.01$ & $108.89 \pm 8.40$ & $<0.0001$ \\
\hline HDL-C & $26.00 \pm 4.04$ & $16.33 \pm 5.50$ & $<0.0001$ \\
\hline LDL-C & $27.67 \pm 7.54$ & $50.33 \pm 13.91$ & $<0.0001$ \\
\hline SGOT & $65.75 \pm 10.91$ & $76.58 \pm 14.72$ & 0.003 \\
\hline SGPT & $55.56 \pm 9.69$ & $77.87 \pm 18.34$ & $<0.01$ \\
\hline CK & $246.33 \pm 64.16$ & $322.83 \pm 64.41$ & 0.0012 \\
\hline
\end{tabular}

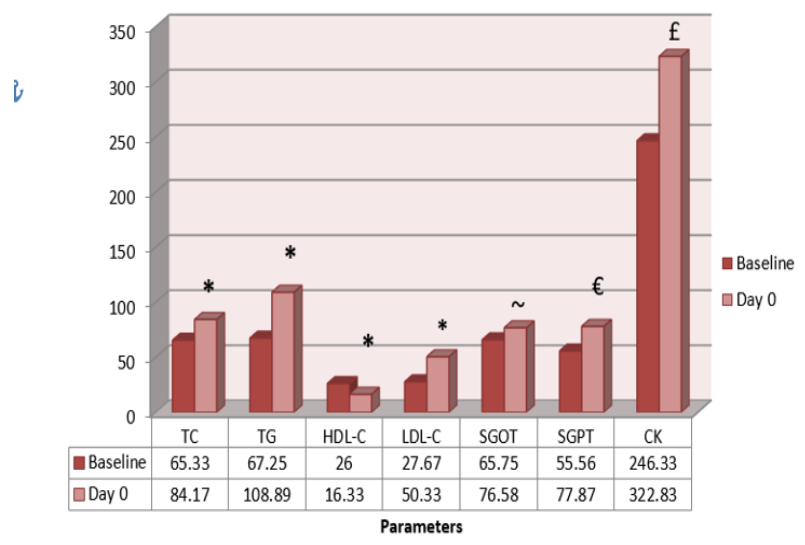

" $p<0.0001, \sim p=0.003, € p<0.01, € p=0.0012)$

\section{Figure 1: Effect of high fat diet on various parameters.}

Table 2a, 2b and Figure 2 show that atorvastatin daily group and atorvastatin alternate day group, both provided a significant reduction in total cholesterol levels as early as week 3 (p - value <0.05). The decrease in TC continued till the end of study [week 6, ( $p$ - value $<0.01)]$. When the treatment regimens were compared, there was no statistical significant difference and both the groups were comparable both at week 3 and week 6 (p value $>0.05$ ). 
Table 2a: Effect of dosing pattern of atorvastatin on total cholesterol at week 3 as compared to day 0 .

\begin{tabular}{|lll|}
\hline Group & $\begin{array}{l}\text { Total cholesterol } \\
(\mathbf{m g} / \text { dl) }(\text { Mean } \pm \text { SD) }\end{array}$ & P - value \\
\hline Day 0 & $84.17 \pm 16.46$ & \\
\hline $\begin{array}{l}\text { High fat diet }+ \\
\text { atorvastatin } \\
(5 \mathrm{mg} / \mathrm{kg}) \text { daily }\end{array}$ & $71 \pm 13.49$ & $<0.05$ \\
\hline $\begin{array}{l}\text { High fat diet }+ \\
\text { atorvastatin } \\
\begin{array}{l}\text { (5mg/kg) } \\
\text { alternate day }\end{array}\end{array}$ & $72 \pm 10.64$ & $<0.05$ \\
\hline
\end{tabular}

Table 2b: Effect of dosing pattern of atorvastatin on total cholesterol at week 6 as compared to day 0.

\begin{tabular}{|lll|}
\hline Group & $\begin{array}{l}\text { Total cholesterol } \\
(\mathrm{mg} / \mathrm{dl})(\text { Mean } \pm \text { SD })\end{array}$ & P - value \\
\hline Day 0 & $84.17 \pm 16.46$ & \\
\hline $\begin{array}{l}\text { High fat diet }+ \\
\text { atorvastatin } \\
(5 \mathrm{mg} / \mathrm{kg}) \text { daily }\end{array}$ & $63.50 \pm 14.76$ & $<0.01$ \\
\hline $\begin{array}{l}\text { High fat diet }+ \\
\text { atorvastatin } \\
\begin{array}{l}\text { (5mg/kg) } \\
\text { alternate day }\end{array}\end{array}$ & $<7.00 \pm 9.32$ & $<0.01$ \\
\hline
\end{tabular}

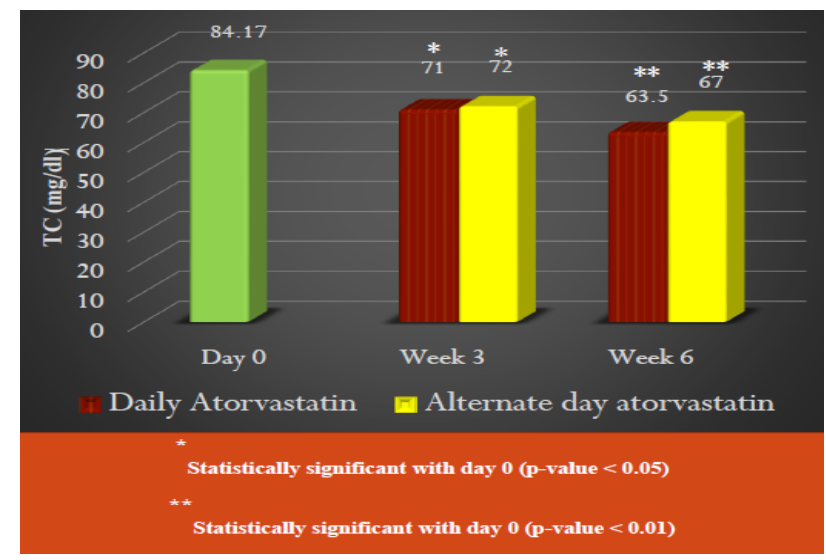

Figure 2: Effect of daily atorvastatin vs alternate day atorvastatin on serum total cholesterol (TC).

Table 3a: Effect of dosing pattern of atorvastatin on serum triglycerides at week 3 as compared to day 0 .

\begin{tabular}{|c|c|c|}
\hline Group & $\begin{array}{l}\text { Triglyceride }(\mathrm{mg} / \mathrm{dl}) \\
(\text { Mean } \pm \text { SD) }\end{array}$ & P - value \\
\hline Day 0 & $108.89 \pm 8.40$ & \\
\hline $\begin{array}{l}\text { High fat diet }+ \\
\text { atorvastatin }(5 \mathrm{mg} / \mathrm{kg}) \\
\text { daily }\end{array}$ & $81.17 \pm 14.16$ & $<0.05$ \\
\hline $\begin{array}{l}\text { High fat diet }+ \\
\text { atorvastatin }(5 \mathrm{mg} / \mathrm{kg}) \\
\text { alternate day }\end{array}$ & $101 \pm 9.27$ & $>0.05$ \\
\hline
\end{tabular}

Table 3b: Effect of dosing pattern of atorvastatin on serum triglycerides at week 6 as compared to day 0 .

\begin{tabular}{|c|c|c|}
\hline Group & $\begin{array}{l}\text { Triglyceride }(\mathrm{mg} / \mathrm{dl}) \\
(\text { Mean } \pm \text { SD) }\end{array}$ & P - value \\
\hline Day 0 & $108.89 \pm 8.40$ & \\
\hline $\begin{array}{l}\text { High fat diet }+ \\
\text { atorvastatin } \\
(5 \mathrm{mg} / \mathrm{kg}) \text { daily }\end{array}$ & $70.17 \pm 16.03$ & $<0.01$ \\
\hline $\begin{array}{l}\text { High fat diet }+ \\
\text { atorvastatin } \\
(5 \mathrm{mg} / \mathrm{kg}) \\
\text { alternate day }\end{array}$ & $73.00 \pm 7.97$ & $<0.01$ \\
\hline
\end{tabular}

Table $3 \mathrm{a}, 3 \mathrm{~b}$ and Figure 3 show that atorvastatin daily dosing group provided a significant reduction in triglyceride levels measured at week 3 as compared to day 0 ( $\mathrm{p}$ - value $<0.05)$, however the reduction in triglyceride levels at week 3 was not significant in atorvastatin alternate day group when compared to day 0 ( $\mathrm{p}$ - value >0.05). Pairwise comparison revealed a significant difference in between the daily dosing and alternate day dosing regimen of atorvastatin at week 3 (pvalue $<0.05)$. The decrease in triglyceride levels at week 6 in both the treatment groups was significant when compared to day 0 ( $\mathrm{p}$ - value $<0.01)$. Also the decrease in triglycerides was comparable when both the treatment groups were compared at week 6 ( $\mathrm{p}$ - value $>0.05$ ).

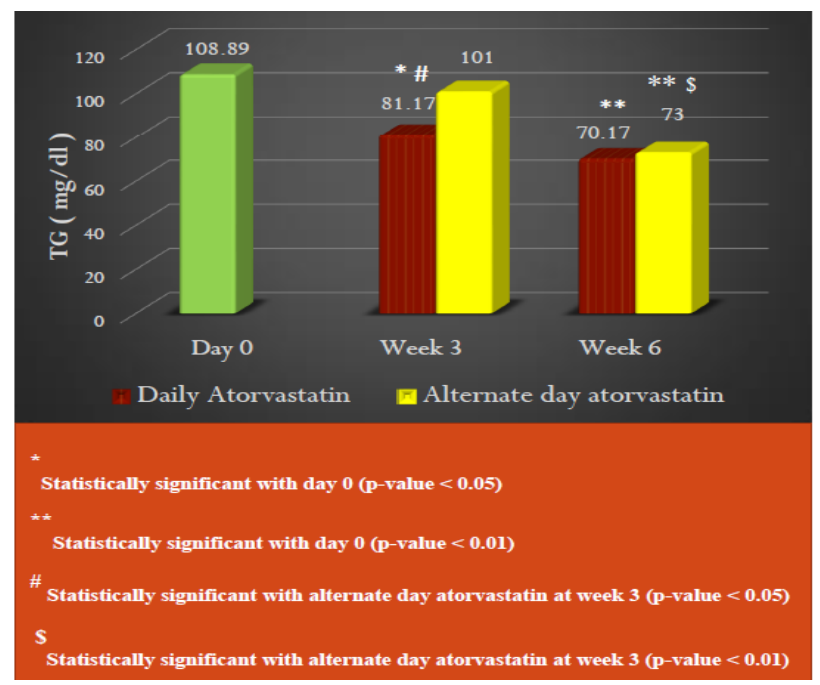

Figure 3: Effect of daily atorvastatin vs alternate day atorvastatin on serum triglycerides (TG).

Table 4a, 4b and Figure 4 show that none of the treatment regimens provided a significant increase in HDL-C levels at week 3 ( $\mathrm{p}$ value >0.05). However at week 6, atorvastatin daily dosing group, provided a significant increase in HDL - $\mathrm{C}$ levels as compared to day 0 ( $\mathrm{p}$ value < 0.01$)$. The rise in HDL - $\mathrm{C}$ in alternate day dosing regimen of atorvastatin was modest, however it was not statistically significant as compared to day 0 at week 6 (p- value $>0.05$ ). Pairwise comparison showed statistical 
difference in between the treatment groups at week 6 (p value $<0.05)$.

Table 4a: effect of dosing pattern of atorvastatin on serum HDL at week 3 as compared to day 0.

\begin{tabular}{|lll|}
\hline Group & $\begin{array}{l}\text { HDL-C }(\mathrm{mg} / \mathrm{dl}) \\
(\text { Mean } \pm \text { SD })\end{array}$ & P - value \\
\hline Day 0 & $16.33 \pm 5.50$ & \\
\hline $\begin{array}{l}\text { High fat diet }+ \\
\text { atorvastatin }(5 \mathrm{mg} / \mathrm{kg}) \\
\text { daily }\end{array}$ & $18.00 \pm 4.29$ & $>0.05$ \\
\hline $\begin{array}{l}\text { High fat diet }+ \\
\text { atorvastatin }(5 \mathrm{mg} / \mathrm{kg}) \\
\text { alternate day }\end{array}$ & $16.00 \pm 6.63$ & $>0.05$ \\
\hline
\end{tabular}

Table 4b: Effect of dosing pattern of atorvastatin on serum HDL at week 6 as compared to day 0.

\begin{tabular}{|lll|}
\hline Group & $\begin{array}{l}\text { HDL-C }(\mathrm{mg} / \mathrm{dl}) \\
(\text { Mean } \pm \text { SD })\end{array}$ & P - value \\
\hline Day 0 & $16.33 \pm 5.50$ & \\
\hline $\begin{array}{l}\text { High fat diet }+ \\
\text { atorvastatin } \\
(5 \mathrm{mg} / \mathrm{kg}) \text { daily }\end{array}$ & $22.17 \pm 1.94$ & $<0.01$ \\
\hline $\begin{array}{l}\text { High fat diet }+ \\
\text { atorvastatin } \\
\begin{array}{l}(5 \mathrm{mg} / \mathrm{kg}) \text { alternate } \\
\text { day }\end{array}\end{array}$ & $18.00 \pm 6.00$ & $>0.05$ \\
\hline
\end{tabular}

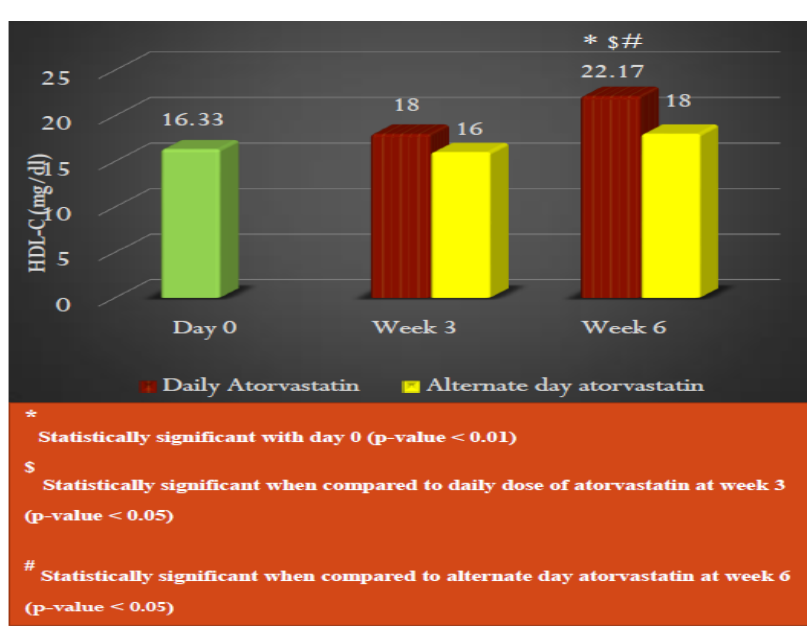

Figure 4: Effect of daily atorvastatin vs alternate day atorvastatin on serum HDL-C.

Table 5a, 5b and Figure 5 show that atorvastatin daily dosing and alternate day dosing, both the groups provided a significant reduction in serum LDL-C levels measured at week 3 and week 6 as compared to day $0(\mathrm{P}$ - value $<0.05, \mathrm{P}$ - value $<0.01$ respectively). Pairwise comparison did not show any significant difference in between the treatment groups at week 3 and week 6 ( $\mathrm{p}$ - value >0.05).
Table 5a: Effect of dosing pattern of atorvastatin on serum LDL-C at week 3 as compared to day 0.

\begin{tabular}{|lcc|}
\hline Group & $\begin{array}{l}\text { LDL-C }(\mathrm{mg} / \mathrm{dl}) \\
(\text { Mean } \pm \text { SD })\end{array}$ & P - value \\
\hline Day 0 & $50.33 \pm 13.91$ & \\
\hline $\begin{array}{l}\text { High fat diet }+ \\
\text { atorvastatin }(5 \mathrm{mg} / \mathrm{kg}) \\
\text { daily }\end{array}$ & $37.50 \pm 11.67$ & $<0.05$ \\
\hline $\begin{array}{l}\text { High fat diet }+ \\
\text { atorvastatin }(5 \mathrm{mg} / \mathrm{kg}) \\
\text { alternate day }\end{array}$ & $38.00 \pm 4.86$ & $<0.05$ \\
\hline
\end{tabular}

Table 5b: Effect of dosing pattern of atorvastatin on serum LDL-C at week 6 as compared to day 0.

\begin{tabular}{|lll|}
\hline Group & $\begin{array}{c}\text { LDL-C }(\mathbf{m g} / \mathbf{d l}) \\
(\text { Mean } \pm \text { SD) }\end{array}$ & P - value \\
\hline Day 0 & $50.33 \pm 13.91$ & \\
\hline $\begin{array}{l}\text { High fat diet }+ \\
\text { atorvastatin }(5 \mathrm{mg} / \mathrm{kg}) \\
\text { daily }\end{array}$ & $27.33 \pm 14.67$ & $<0.01$ \\
\hline $\begin{array}{l}\text { High fat diet }+ \\
\text { atorvastatin }(5 \mathrm{mg} / \mathrm{kg}) \\
\text { alternate day }\end{array}$ & $31.54 \pm 5.88$ & $<0.01$ \\
\hline
\end{tabular}

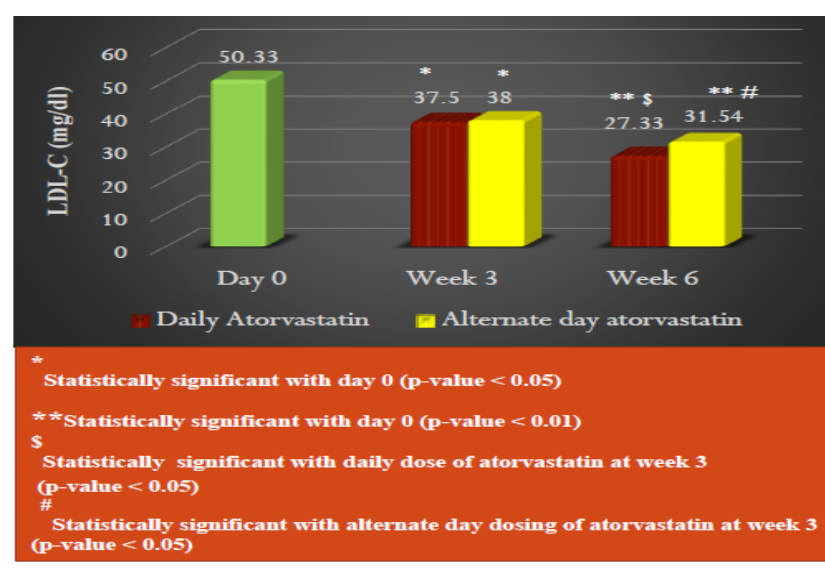

Figure 5: Effect of daily atorvastatin vs alternate day atorvastatin on serum LDL-C.

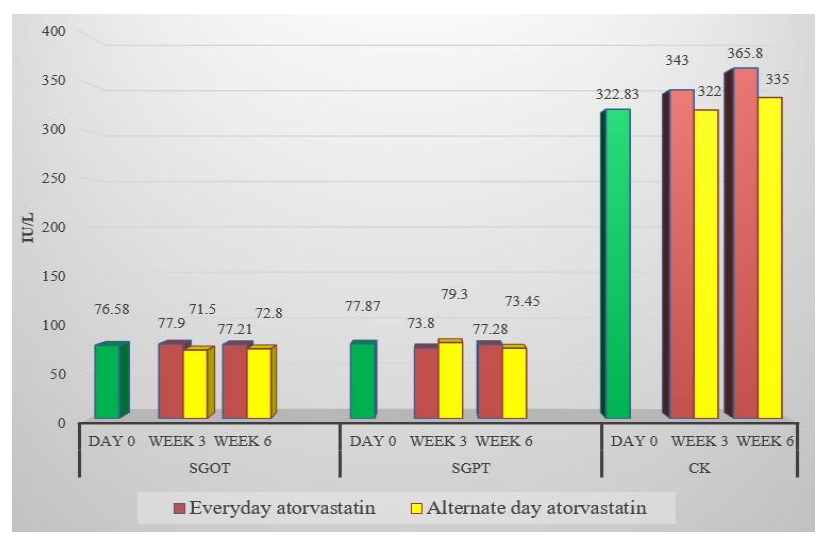

Figure 6: Effect of daily atorvastatin vs alternate day atorvastatin on serum SGOT, SGPT and CK. 
Figure 6 shows that there was no statistically significant difference in SGOT, SGPT and CK levels in both the dosing regimens as compared to day 0 , at week 3 and week $6(\mathrm{p}-$ value $>0.05)$. As the $\mathrm{p}$ - value is greater than 0.05 and is not statistically significant pairwise comparison was not made.

\section{DISCUSSION}

Statins play a vital role in the prevention of atherosclerotic cardiovascular complications and statin therapy continues to be a mainstay in treating patients with hyperlipidemia. However compliance to statins is often reduced due to myopathy which is commonly observed side effect of these drugs. Painless myopathy from statin therapy is also quite common and may be rather dangerous because it is often ignored. Statins have also been associated with increase in liver transaminases as they lead to hepatic injury. In view of the above alternate day regimen can be a better alternative provided that it would also be cost effective.

Our results show that atorvastatin daily as well as alternate day dosing regimen, effectively decreased TC, LDL-C and TG at the end of 6 weeks without any significant difference between them. These findings are cohesive with Pramanik S et al, Jafari $\mathrm{M}$ et al, Matalka $\mathrm{MS}$, et al and Aghosadeghi $\mathrm{K}$ and Zare et al. ${ }^{6-9}$

A prospective, open label, crossover study in 40 patients conducted by Pramanik $S$ et al evaluating the efficacy of alternate day atorvastatin versus daily dosing showed that both treatment regimens significantly reduced TC and TG and LDL-C levels as compared to baseline. There was no statistically significant difference between the two groups in terms of reduction of TC, TG and LDL-C at 12 weeks of treatment.

Jafari $\mathrm{M}$ et al studied the efficacy of alternate day versus everyday dosing of atorvastatin in 46 patients. Both the treatment groups significantly reduced TC and LDL-C levels compared to baseline and pairwise comparison did not show any statistical difference in between the treatment groups.

Matalka MS et al studied 35 hypercholesterolemia patients in a double blind, placebo controlled design for 12 weeks. Authors concluded that alternate day atorvastatin produced a significant reduction in LDL-C that was comparable to daily administration ( $\mathrm{p}$ - value $>0.05)$.

The authors Aghosadeghi K and Zare D evaluated the efficacy of alternate-day dosing of atorvastatin in comparison with the standard one-daily dose. No statistically significant difference existed between the treatment groups in regards to total or a percentage decrease in triglyceride levels at 6 weeks compared to baseline.
Our study shows that alternate day atorvastatin therapy lacks efficacy over everyday therapy in terms of increase in HDL-C. This finding is in accordance with Piamsomboon, et al who studied the efficacy and safety of atorvastatin $10 \mathrm{mg}$ every other day in 61 patients with hypercholesterolemia for 8 weeks and concluded that the increase in high density lipoprotein-cholesterol (HDL-C) level was not statistically significant with alternate day atorvastatin therapy. ${ }^{10}$

In large clinical trials, evidence is mixed regarding the potential benefit of increasing HDL-C even when LDL-C is very low. Normalization of HDL-C is desirable, but not as essential as reduction of LDL-C. Some studies show that HDL-C levels remain predictive of risk, while other studies show that it is not. ${ }^{11,12}$

In view of the above findings we can say that alternate day regimen is as effective as everyday dosing in treating hyperlipidemia.

There was no statistically significant difference in SGOT, SGPT and CK levels in both the dosing regimens as compared to day 0 , at week 3 and week 6 .

This shows that both the treatment regimens were equally safe.

Our results are in compliance with Aghosadeghi K et al who have studied the efficacy and safety of alternate day versus everyday treatment of atorvastatin in 60 patients. ${ }^{9}$ The authors found no incidence of elevated liver enzymes or creatine kinase levels in any of the treatment groups and there was no statistical difference in SGOT, SGPT and CK levels between the treatment groups.

Jafari $M$ et al studied the efficacy of alternate day versus everyday dosing of atorvastatin in 46 patients. ${ }^{7}$ Both the regimens were well tolerated and none of the patients had a significant elevation of liver enzymes or creatine kinase. Group wise comparison did not show any statistical difference in SGOT, SGPT and CK levels.

From our study, it can be appreciated that the rise in CK level was consistently higher in everyday atorvastatin group at week 3 and week 6 as compared to alternate day atorvastatin group. The difference however was not statistically significant. This might suggest that increase in study duration or chronic use of everyday atorvastatin (which parallels the duration of use of atorvastatin in treatment of patients with hyperlipidemia) in our study could had resulted in cumulative and statistically significant increase in $\mathrm{CK}$ levels which at a later stage might reflect in a clinically significant myopathy. It would not be an assumption to say that alternate day dosing is a better and safe alternative than everyday dosing of atorvastatin given the background that statins are prescribed lifelong. 


\section{Cost effectiveness}

Though statins play a central role in cardiovascular risk reduction, only half the patients prescribed a statin adhere to this therapy. ${ }^{13}$ Non adherence is the main reason why patients do not achieve LDL goals, and in effect have worsened clinical outcomes. ${ }^{14}$ Higher healthcare costs is another issue for non-adherence. ${ }^{15}$ For some patients, side effects lead to discontinuation, while others underestimate the importance of statin therapy because of the asymptomatic nature of hyperlipidemia. In our study we found that alternate day therapy was at par with everyday dosing in terms of efficacy and safety.

Alternate-day statin therapy can be used as an alternative to everyday dosing in order to decrease cost and therapylimiting adverse reactions while potentially increasing regimen adherence and positively affecting the lipid panel. However further research is needed to determine whether this alternative regimen produces similar cardiovascular outcomes as those with daily statin therapy.

\section{CONCLUSION}

From the present study we can conclude that alternate day dosing of atorvastatin was as efficacious and safe as everyday dosing of atorvastatin in hyperlipidemic New Zealand White rabbits, thus being a cost effective alternative.

Every day as well as alternate day dosing, both the regimens of atorvastatin administration in the dose of $5 \mathrm{mg} / \mathrm{kg}$ body weight have shown significant hypolipidemic activity in hyperlipidemic rabbits which was statistically significant.

Every day atorvastatin showed a significant increase in HDL-C levels when compared to day 0 which was not seen with alternate day dosing.

There was no significant rise in SGOT and SGPT levels in both the dosing regimens when compared to day 0 .

There was also no statistically significant difference in CK levels when both the dosing regimens were compared. However the rise in CK levels was numerically more in everyday dosing of atorvastatin than the alternate day dosing regimen. This again warrants long term studies with frequent estimation of CK levels where, alternate day dosing regimen of atorvastatin might have a clinically meaningful impact in terms of reducing the symptoms of myopathy, especially painless myopathy which is quite common and dangerous because it is often ignored.

Data regarding the efficacy and safety of alternate day dosing of atorvastatin as compared to everyday dosing is sparse. Most importantly all the clinical studies are short term studies and most of them have excluded old age patients with concurrent medications and illness. This heightens safety concerns, both because the polypharmacy typical of this age group greatly increases the overall risk of drug-drug interactions and because many of the diseases common in older patients contribute to drug safety concerns, and finally, because advanced age itself, even with excellent health, probably increases the risk of drug toxicity. So, large clinical trials with adequate duration, proper enrolment and randomization of patients would be required to see the potential benefit of alternate day dosing regimen over everyday regimen in terms of safety and efficacy. These kinds of studies would also reflect the actual incidence of myopathy in real time world.

\section{Funding: No funding sources}

Conflict of interest: None declared

Ethical approval: The study was approved by the Institutional Ethics Committee

\section{REFERENCES}

1. Baigent C, Keech A, Kearney PM. Efficacy and safety of cholesterol lowering treatment: prospective meta - analysis of data from 90,056 participants in 14 randomized trials of statins. Lancet. 2005;366:1267-78.

2. Statin Therapy: Risks vs Benefit: An Expert Interview With Eliot A. Brinton, MD. 2015 [cited 2015 May 8] Available from www.medscape.org/viewarticle/481357

3. Brunton LL, Chabner BA, Knollmann BC. In, Goodman \& Gilman's. The Pharmacological Basis of Therapeutics. 12th edition. California. The Mc Graw-Hill Companies, Inc. Drug therapy for hypercholesterolemia and dyslipidemia. 2011:896.

4. Suzuki M, Kakuta H, Takahashi A, Shimano H, Tada-lida $\mathrm{k}$ et al. Effects of Atorvastatin on glucose metabolism and insulin resistane in KK/Ay mice. $\mathbf{J}$ Atherosclerosis Thrombosis. 2004;12(2):77-84.

5. Purohit A, Joshi K, Kotru B, Kotru S, Ram H. Histological study of antiatherosclerotic effect of Propolis in induced hypercholestrolemic male albino Rabbits. Indian J Life sciences. 2012;2(2):384-90.

6. Pramanik S, Das AK, Chakrabarty M, Bandopadhyay SK, Ghosh M, Dalai CK. Efficacy of alternate-day versus everyday dosing of atorvastatin. Indian J Pharmacol. 2012;44(3):362-5.

7. Jafari M, Ebrahimi R, Ahmadi-Kashani M, Balian $\mathrm{H}$, Bashir M. Efficacy of alternate-day dosing versus daily dosing of Atorvastatin. J Cardiovasc Pharmacol Ther. 2003;8(2):123-26.

8. Matalka MS, Ravnan MC, Deedwania PC. Is alternate daily dose of Atorvastatin effective in treating patients with hyperlipidemia? The Alternate Day Versus Daily Dosing of Atorvastatin Study (ADDAS). Am Heart J. 2002;144(4):674-77.

9. Aghosadeghi K, Zare D. Efficacy of alternate day dosing of Atorvastatin. Journal of Chinese Clinical Medicine. 2007;2(10):163-6. 
10. Piamsomboon C, Laothavorn P, Saguonwong S, Chatloong B, Nasawadi C, Tanprasert P. Efficacy and safety of atorvastatin $10 \mathrm{mg}$ every other day in hypercholesterolemia. J Med Assoc Thai. 2002;85(3):297-300.

11. Barter P. HDL Cholesterol, very low levels of LDL Cholesterol, and cardiovascular events. N Engl J Med. 2007;357:1301-10.

12. Ridker PM. HDL cholesterol and residual risk of first cardiovascular events after treatment with potent statin therapy: an analysis from the JUPITER trial. Lancet. 2010;376:333-9.

13. Benner JS, Glynn RJ, Mogun H, Neumann PJ, Weinstein MC, Avorn J. Long-term persistence of statin therapy in elderly patients. JAMA. 2002;288:455-61.
14. Rasmussen JN, Chong A, Alter DA. Relationship between adherence to evidence-based pharmacotherapy and long-term mortality after acute myocardial infarction. JAMA. 2007;297:177-86.

15. Goldman DP, Joyce GF, Karaca-Mandic P. Varying pharmacy benefits with clinical status: the case of cholesterol lowering therapy. Am J Manag Care. 2006;12:21-8.

Cite this article as: Mulkalwar S, Golande P. To compare the efficacy of alternate day versus everyday dosing of atorvastatin in hyperlipidemic rabbits. Int $\mathbf{J}$ Basic Clin Pharmacol 2016;5:434-41. 